\title{
ARCHIVE RESEARCH AS A DIAGNOSTIC AND COGNITIVE INVESTIGATIVE METHOD OF MEMORY OF THE MULTISTRATIFIED URBAN BUILT HERITAGE: A CASE OF URBAN ARCHEOLOGY
}

\author{
LUCREZIA LONGHITANO, SANTI M. CASCONE, \\ STEFANO CASCONE \& GIUSEPPE A. LONGHITANO \\ University of Catania, Italy
}

\begin{abstract}
The urban contexts that we live today are often the result of a stratification spontaneously followed over time, incorporating buildings in use in ancient times but abandoned as a result of the historical and cultural evolution of the city. This situation is very frequent in many historical centers, where archaeological buildings are located below the modern urban plan. An exemplary case of this situation is given by the Roman amphitheater of Catania. It was covered and used as a substructure for the new plan steal and for the buildings rebuilt after the earthquake of 1693 that destroyed the city. These reconversions of ancient structures cause several conservative problems, often difficult to understand and which must be investigated in an interdisciplinary way to understand their origins and solve them. The complexity of urban systems requires an inevitable multidisciplinary approach that combines archival analysis, historical, archaeological analysis, diagnostics, architectural, plant engineering and urban. This research aims to show, in particular, how the part of historical analysis of archival type can be a useful diagnostic survey tool to be applied in multi-layered contexts, through the example of the Roman amphitheater of Catania which today is in a precarious state of conservation and accessibility that requires intervention. This work was carried out by studying the administrative documentation of the 19th century produced by responsables for the protection of the historical buildings of Catania, kept at the State Archive of Catania, and allowed to understand the conservative events of the heritage architectures and to deepen the knowledge of the causes of the degradation that today the monument undergoes, demonstrating how such problems have a long history never radically resolved.

Keywords: urban stratification, archive research, history of conservation, diagnostic.
\end{abstract}

\section{INTRODUCTION}

Today, the archaeological and historical building heritage is part of a complex and stratified urban system. The natural growth of cities has led to the creation of urban archaeology contexts that affect the conservation of the oldest heritage. By natural overlap and development, the oldest heritage is incorporated and subjected to the construction of subsequent eras. Examples are the Roman Marcello's theater surmounted by the latter stratified building, the Crypta Balby, the Domizian's stadium whose shape is legible from the buildings surrounding piazza Navona, the temple of Athena in Ortigia incorporated in the construction of the Cathedral and many others. An urban context offering several examples of these stratifications is the city of Catania, founded by Greeks and reconstructed by Romans. After an uninterrupted development until the medieval phase, it underwent an important break due to the earthquake in 1693 that devastated the city. From this moment, the reconstruction restarted with a new planning incorporating the old buildings, e.g. the Roman ruins such as the Greek-Roman theater, the odeon, the Roman bath named Terme Achilliane and the amphitheater, with priority assigned to the new late-baroque urban plant, existing until today [1]. 
Focusing on the case of the amphitheater, that is subject of this research, it is incorporated in the urban stratification following the earthquake of 1693, in the area of Piazza Stesicoro (Fig. 1). Among the original 56 sectors, only 22 remain, divided between an uncovered area, visible from the square and set up in 1906, and a hypogea area, underlying modern structures.

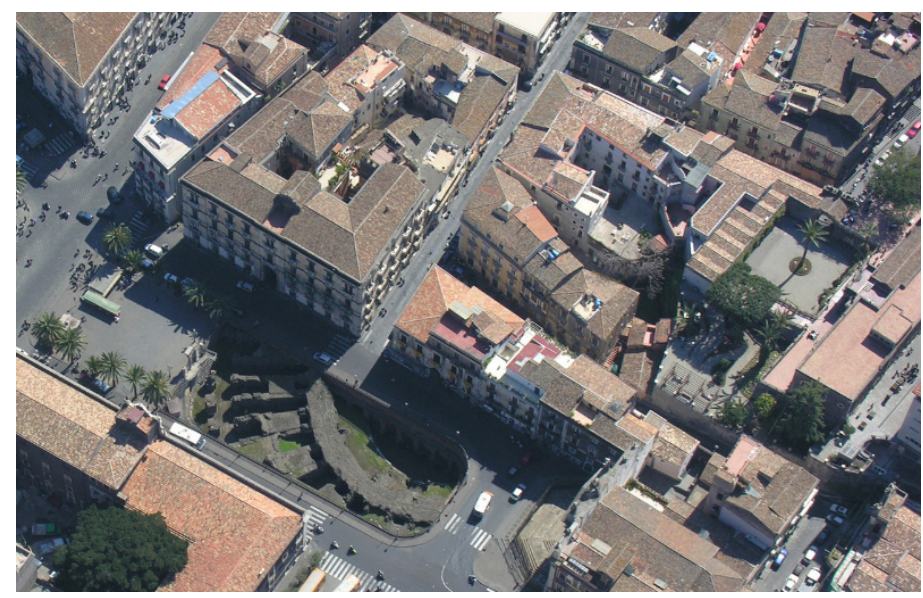

Figure 1: Piazza Stesicoro overlooking the ruins of the amphitheater, north-west view. (Source: Poloregionale.net.)

The hypogeal area has problems due to the unnatural location, and these are: structural, being the ruins used as substructures, and conservative, due to the continuous infiltrations from the upper floors. This situation is compromising the use of the monument and it would be necessary to plan cognitive survey of the ancient structures and the upper urban stratification, with multidisciplinary approaches, in order to prevent it from getting worse. In fact, it is necessary to investigate the conditions and causes of degradation through environmental and material analysis, monitoring performance and historical-archaeological studies to understand the phases, transformations, possible damages and restorations, without neglecting the study of the relationship, over time, between the amphitheater and the upper layers, trying to understand the sequence, evolution and plan systems of the latter construction. It is important that any intervention is aimed to the full enjoyment of the monument, supported by a careful basis of studies that goes back in time to understand not only the conservation history of the building but also to discover information on the development of degradation phenomena and their causes [2]. During the course of this study, in addition to the direct approach to the building, an important support is given by the study of historical and archival documentation. In fact, it is interesting to show how archival research could add information on the conservative history and degradation, representing a useful diagnostic tool.

\section{PRESENTATION OF THE CASE STUDY OF URBAN ARCHEOLOGY}

The multi-layered context of Catania joins two important "urban layers" of the city: a Roman time layer, represented by the amphitheater, and the later baroque layer, which was built after the earthquake in 1693. The area where the amphitheater was built during the imperial era is a sloping soil, at the base of the Montevergine hill which was the northern boundary of the Roman city lapped by the ancient walls. This part of the city was important for the Regis 
gate, in which came close to the Via Pompeia (connecting Catania to Messina), and for this it was enhanced by the Emperor Hadrian [3]. Although starting from the 11th century the religious and political core of the city moved to the south, with the construction of the Cathedral, the northern area remained an important area due to the presence of the church of St. Agata la Vetere, saint of the city [4]. After the earthquake in 1693, the reconstruction of new urban area, incorporating the rest of the amphitheater, the adjacent 16th-century walls and the rest of the medieval city, was directed by the Duke of Camastra G. Lanza [5].

This area is part of the Piazza Stesicoro, between Via dei Cappuccini to the North, Via Penninello and Via Cerami to the South, Via Alessandro Manzoni to the East and Via Gallo to the West (Fig. 2).

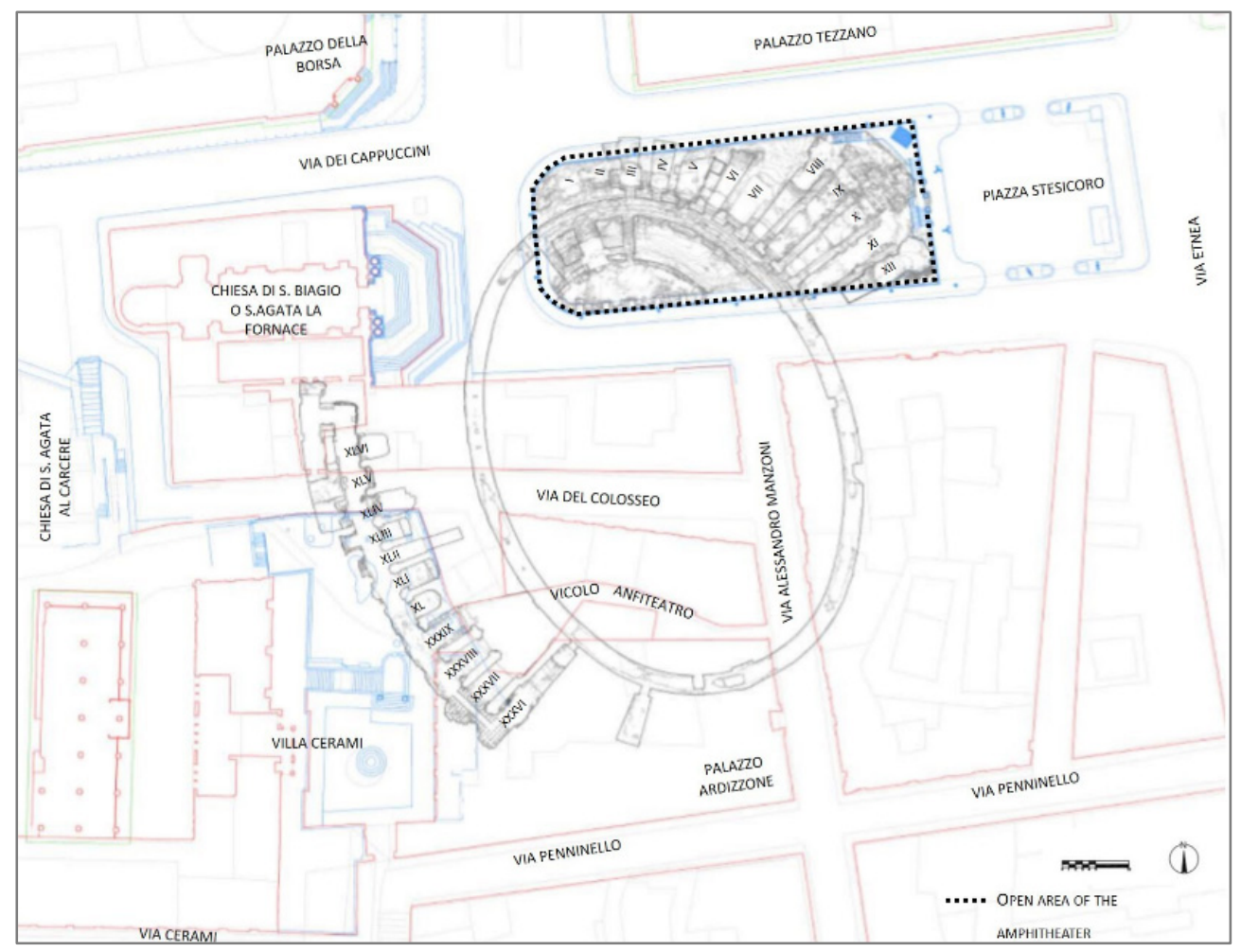

Figure 2: Framing of the amphitheater. (Source: Malfitana, Mazzaglia 2018, graphic reworking by L. Longhitano.)

It is not clear if this area is the result of urban planning, or it is more likely a spontaneously system established as result of urban growth [6]. However, the attention to this area grew at the beginning of the 18th century, when started an expansion northward. The gentry was the first encouraging construction in this area, commissioning many buildings such as: Palazzo Tezzano, Palazzo del Toscano and, above all, the Villa of the Prince of Cerami (or Villa Cerami), provided with a roof garden supported by the amphitheater arches and by part of the 16th-century bastions [7]. At the same time, the Benedictine order intervened by rebuilding the church of St. Agata la Vetere and started the churches of St. Agata al Carcere 
and St. Biagio or St. Agata la Fornace, continuing to exploit the walls and the vaults of the amphitheater [8] (Fig. 3). Therefore, the medieval and Roman ruins were totally hidden and used as foundations. The re-discovery of the amphitheater, as consequence of the new urban plan, started progressively from the mid-1700s when Ignazio Paternò Castello, Prince of Biscari, began the excavation of the external corridor and the western façade of the structure, facing the hill Montevergine. These activities were consistent with the 18th century idea of rediscovering antiquities [9]. In 1841, the excavations started under the supervision of Francesco Saverio Cavallari and Domenico Lo Faso Pietrasanta. In this phase, a sector was dug to connect the middle ambulatory with the internal one, and the two main entrances, located on the major and minor axis of the arena, were discovered. In 1875, walls and portions of the lava stone cornice were found under some houses in Via Penninello. The last phase of discovery of the building was in 1904-1906 when Filadelfo Fichera freed the cavea, the wall of the podium, the corridor adjacent to the podium below the cavea and a "precinct" separating the arena from the base of the stairs. In this phase, in line with a desire for urban enhancement through ancient memories, the Piazza Stesicoro square was partly opened, creating the view to the monument that exist today. In the next years, new portions were not added to those excavated, but the interventions and studies continued. In the 1970s and 1980s, there were the restoration and consolidation of the amphitheater's arches in the south-western area, located below the Villa Cerami. In 1996 a campaign of interdisciplinary studies was carried out, consisting in an in-depth analysis of archaeological excavations, geologic surveys and shoring; in 1997, in Via Penninello, some archaeological parts emerged, following works, which led to new investigations. The latest interventions and studies were carried out in 2006, with the participation of the Germanic Archaeological Institute in Rome [10].

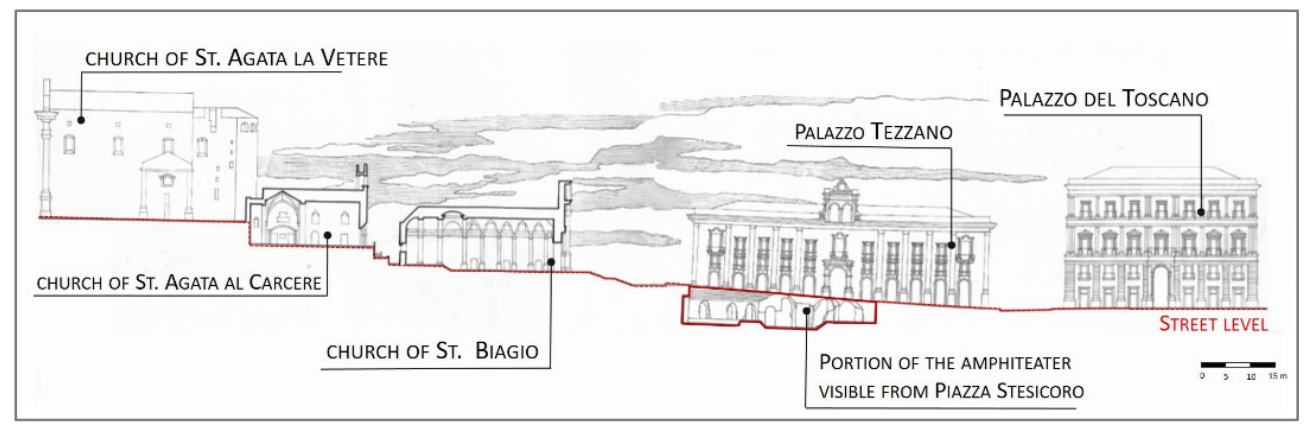

Figure 3: Section of the Piazza Stesicoro. (Source: Quaderni dell'Istituto di disegno, 2, 1967, graphic reworking by L. Longhitano.)

\section{THE STATE OF THE MONUMENT: CONSERVATIVE PROBLEMS}

Today, the amphitheater has a different condition from the original one. It was designed as an "above-ground" structure, however, today it is located underground and it is used as foundation and support of numerous structures, areas and houses characterized by important architectural value (Fig. 4). Over time, this unnatural condition has led to many problems, especially since the 18th century, i.e. structural collapses that required the construction of both concrete and temporary shoring, and degradation phenomena. In particular, walking through the ambulatory, there is the presence of biological colonization, efflorescence, perennial infiltrations and drips, which don't allow a pleasant and real enjoyment of the monument, as well as acting negatively on the Roman vaults and walls. The current condition 
is not easy to investigate, because the amphitheater is a system made up of different parts in heterogeneous conditions and subject to a complex stratification. In light of this situation, studies and projects have been ongoing for many years with the aim of securing and enhancing the underground portion [11].

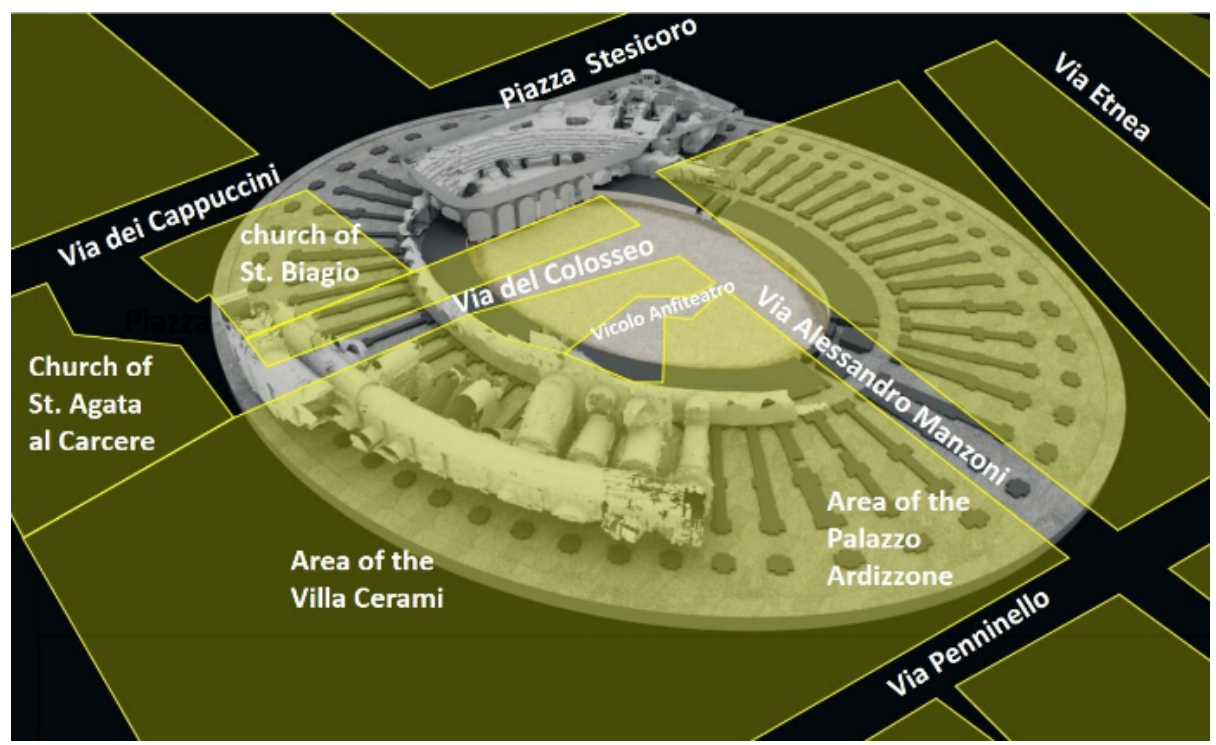

Figure 4: Surviving parts of the amphitheater with the new building in yellow. (Graphic reworking, by L. Longhitano, of laser scanner made by ISPC-CNR of Catania.)

Recent studies [12] have deepened the analysis of the XXXVI surviving sectors, (see Fig. 2 ), located in the underground part, that is the only intact sector and connection point between the internal and external ambulatory, even if it is seriously compromised by the decay phenomena. The analysis carried out allowed to understand the main manifested degradation phenomena such as deposits, efflorescence and various types of encrustations.

These encrustations, following the X-ray diffractometry analysis, have been distinguished into three types: chalky encrustations (Type 1) in all walls of the sector (conditioned by the rising and lateral infiltrations of water crossing the higher layers) and carbonate encrustations (Type 2-Type 3) derived from the dissolution of the mortar binder of the Roman vaults in opus caementicium (lime mortar and stones), due to the infiltrations (Fig. 5).

Therefore, the main causes of degradation are infiltrations, however, it is not easy to understand the origin. It requires an in-depth study of the context through the integration of different approaches, applied to the entire building, because the precarious condition of XXXVI sector is not isolated but similar scenarios were found in other parts of the structure.

Considering this situation, this study proceeded by carrying out an analysis of the evolution of the upper urban context through the study of historical cartography which demonstrated how the current system was organized in the 18th century and was not changed.

Especially, the authors made a detailed study of the archival documentation concerning the historical and artistic heritage of the city of Catania and, in particular, concerning the amphitheater, in order to find more information on conservative history of the building as detailed in the following paragraph [13]. 


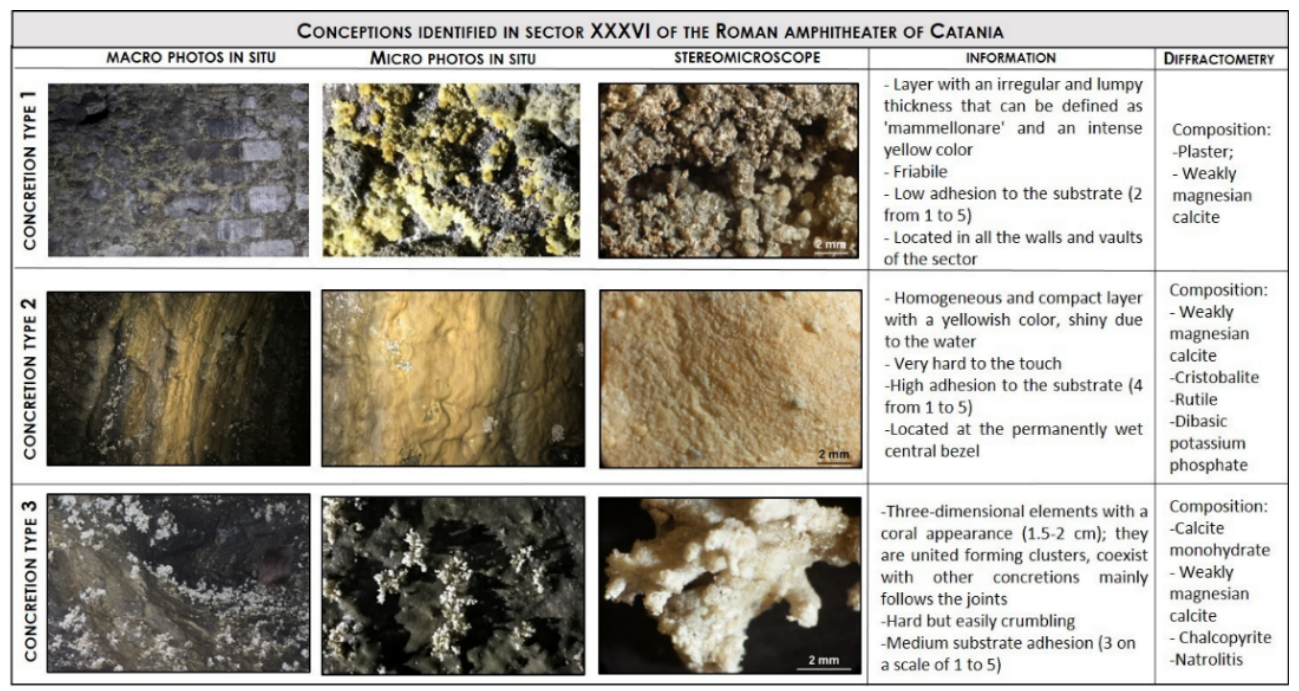

Figure 5: Different types of concretions found in sector XXXVI of the Roman amphitheater of Catania.

\section{RESEARCH METHODOLOGY: ARCHIVE ANALYSIS}

In order to expand the knowledge framework on the history of the amphitheater conservation, the archival documentation preserved in the State Archives of Catania was examined. It dates from the early 19th century, when Sicily prepared new control systems of the antiquities as well as being it was reorganized with a new division into seven Intendencies [14].

Especially, the documentation analyzed belongs to the sections of the Intendenza Borbonica and of the Prefettura of Catania. Concerning the protection policy history implemented in Sicily, in place of older management system of the assets governed by local nobles, appointed royal guardians (called Regi custodi) started since 1778, a Commission (Commissione di Antichità e belle arti di Sicilia) was imposed from 1827 in order to create a more centralized system. By 1830 local commissions were added, as well as collegial bodies, destined to control the peripheral areas [15]. In particular, in Catania, from 1829, a Deputation of Antiquities was also set to ascertain the state of the monuments in Catania considered particularly disfigured [16]. In general, from the 19th century, there was a greater interest in the control and care of assets, which was followed by an increase in exchanges of letters between central and local government. In fact, more information on monuments in Catania can be obtained from letters between various administrative bodies such as: the Intendenza of the Vallo di Catania, the Patrizio of Catania, the Police Station, the Catania's Deputation of Antiquities and from the proceedings of this Deputation.

In particular, for example, from the acts of the sessions in 1830, it is possible learning that the remaining parts of the amphitheater, subject to inspections and discussion, consisted of: ruins, corridors, cavea and part of the portico (Intendenza Borbonica, envelope 643, cc. $587 \mathrm{r}$ ). This research carried out an examination on the latter documentation.

\section{RESULTS AND INFORMATION OBTAINED FROM THE RESEARCH}

It was found that the damage in the amphitheater due to the upper urban layer has characterized the building life for several centuries and, therefore, is not related to the current 
state. The problems are clearly delineated as early as the 19th century and can be attributed to the infiltration, to the use of the building as a landfill and to the lack of a sewerage system to dispose the rainwater that flow from the street level to the ambulatories of the amphitheater placed below. The oldest report is dated 1832, when the caretaker of the monuments urged the authorities to take action to resolve a series of inconveniences due to the use of the amphitheater as a rubbish area by the buildings placed around and above. In particular, it is reported that the sacristans of the parish of S. Agata al Carcere (located near the western area of the amphitheater) continuously threw their rubbish into the "place of antiquity", as well as fellow local merchants. In particular, the master Carmelo Pulvirenti is mentions because the waste water of his workshop was discharged into the internal ambulatory of the amphitheater (Intendenza Borbonica, envelope 643, cc. 695-696). A few years later, in 1838, the same caretaker wrote to the Superintendent of the province to denounce how in the amphitheater there were problems caused by "falling water and other rubbish", this one from the garden adjacent to the amphitheater, owned by Mr. Cappellano Cosentino. It is therefore urged to intervene since this had never been done, causing damage not only to the amphitheater itself but also to visitors (Intendenza Borbonica, envelope 643, cc. 609). In February 1844, the architect Mario Musumeci was designated to carry out emergency work in the ancient buildings of Catania, the architect testified in a report that the most issue to manage is the relationship between the archaeological building and the street upper level. To face the situation, the architect suggested building a circuit walls to avoid use it as a landfill (Intendenza Borbonica, envelope 643, cc. 678-683). However, in the restoration works to be done, dated to 1854, there are still infiltrations for both ambulatories (Intendenza Borbonica, envelope 643 , cc. 554, 556). This report documents that from the vault of the external ambulatory were coming "continuous leaks of water". This water occurred from the garden upstairs belonging to the Prince of Cerami. The same problems also appear on the vault of the internal ambulatory, located below the Mr. Carlo Ardizzone's house and precisely the cause would be the running water used by owners. As interventions, it was suggested, in these old documents, to "expurgate and trim the aqueduct and bring water elsewhere" and bringing the fallen material in one of the surviving compartments.

As some letters from the middle of the 19th century show, expropriating and demolishing the houses that damaged the archaeological ruins was proposed among the available solutions. These problems were discussed for both the amphitheater and the theater. In fact, another important building in Catania, the theater was in the same conditions due to the upper urban layer. The Commission began performing a preliminary estimation on property value and on the compensation to be paid to owners, but these analyses were carried out only for the buildings built on top of the theater and not for the amphitheater. The architectural value of the buildings built above the amphitheater hindered the demolition of the upper house.

These buildings are the Villa Cerami and Professor Ardizzone's house, both emblematic buildings of late baroque architecture in Catania, on which important local architects intervened, such as Giovan Battista Vaccarini and Francesco Battaglia [17], as well as the important churches dedicated to the patron saint of the city. The documents revealed many causes against the owners of the demolished houses above and near the theater, while none for the houses near the amphitheater. As the years passed, even in the aftermath of the unification of Italy in 1861, the problems were not solved, on the contrary they were continued amplified by the administrative changes and centralized decision to detriment of local force.

In 1860, a Central Commission of antiquities in Palermo has been reconfirmed with total jurisdiction over archaeological excavations and restorations but which could avail itself, where necessary, of the advice of provincial commissions. However, communication 
between the center and the periphery had many problems and consequently the Commission's action had trouble, and it was accused of negligence. The inability of the administrative bodies in charge of monument's protection is demonstrated by the existence of problems and the long intervention times, in fact, the Prefect of Catania emphasized that the amphitheater still has problems due to swamping and stagnation of water that flow together. In 1875, in letters discussing the findings in the southern part of the amphitheater incorporated by the houses in Via Penninello, it was notified as beyond the usual drains, in a corridor of the amphitheater (probably below the Ardizzone's properties) disposable water drainage wells were opened (Prefettura, list 14, envelope 258). It was a recurring practice until today. More useful is the documentation drawn up by the Inspector of Monuments Carmelo Sciuto Patti, strongly interested in the protection of Catania's assets and on several occasions he documents the situation [18]. In 1881, Patti urged the municipal administration to intervene urgently the monument after he was being informed about the damage and inconveniences during last many years. These problems concerned the internal ambulatory subject to infiltrations due to the water drained from a sewer in the ascent of the Capuchins below the bell tower of the church of S. Agata la Fornace, where the rainwater converge from Via Botte dell'Acqua and from various aqueducts. The part of the city in question, being at the basis of the Montevergine hill, is sloping morphology towards Piazza Stesicoro, thus favoring a natural channeling towards the amphitheater. There were also problems in other points. In particular, in the portion of the external ambulatory, placed below the Professor Ardizzone's house and the Villa Cerami, where the "unclean waters of the wash houses" flow into.

It is reported that the Prince built on his own initiative, a canal that collected water from the various roofs to bring them right into the amphitheater (Prefettura, envelope 258, series I, list 14). Also, great of interest is the letter written by Sciuto Patti in 1885 where the latter locates and carefully explains the damage in the amphitheater, the related causes and interventions. There are two drawbacks. The first was the infiltration of water, especially in winter times, in the vaults of the external ambulatory, making it uncomfortable to transit, especially due to the stagnated humidity in the clay soil. The second drawback was the humidity involving the internal ambulatory all year round. Regarding the causes, for the Inspector, rains beating on the various houses then flow into the amphitheater. In particular, the house of the Professor Giovanni Ardizzone heirs is denounced (relative of the mentioned Carlo) because dirty water continues draining and is absorbed by the soil and handed down to the vaults of the underlying archaeological ruin. Therefore, such problems are to be found in the South-eastern area of the building. As important intervention, Sciuto Patti proposes to channel all water into special channels to dispose it in a large adjacent area outside the building. The causes of infiltrations in the internal ambulatory are traced back to the poor or "poorly maintained" construction of the municipal aqueducts, under the paving of Via Cappuccini, in the north of Piazza Stesicoro. Regarding the problems, the municipal administrators were repeatedly urged to intervene, but it never happened. Also, the Inspector suggested to repair and to create a disposal system inside the building by opening a well in the most depressed part of the corridor, in order to free it by exploiting the natural internal slope of the soil (Prefettura, section I, list 14, envelope 257). Despite the great interest shown, there was not an effective solution to the problems and this was demonstrated when in 1899 there was still discharges and continuous use of the amphitheater as a garbage dump. These drains always refer to the above buildings and specifically to the Villa Cerami and the chaplaincy of the church of S. Agata la Fornace (Prefettura, section I, list 33, envelope 59).

In 1913, after the liberation of the visible portion in Piazza Stesicoro, Sciuto Patti underlines how the problems still persisted and they were still studying the most appropriate 
way to radically solve the problems of infiltrations, a solution that perhaps still today it was not found. Fig. 6 shows all the possible areas subject to the problems documented by the archival documentations analyzed.

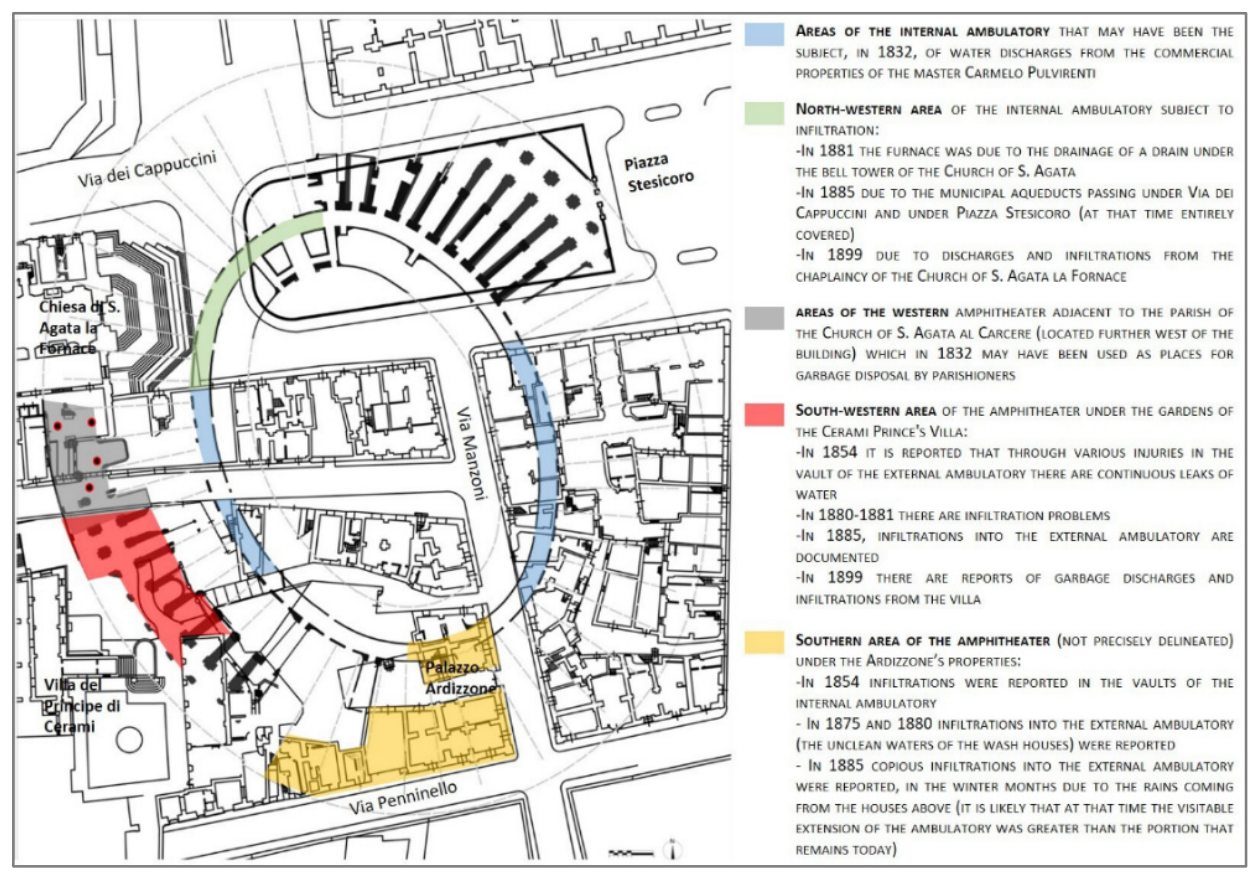

Figure 6: Hypothesis of identification of the areas of the amphitheater subject to discharges and infiltrations cited in the archive documentation.

\section{COMPARISON BETWEEN URBAN AND ARCHIVAL DATA}

At this point, an interesting topic is the attribution of the houses to the owners mentioned by the documents and find out with which current buildings they coincide. From the most updated cadastral surveys of 2015, it is possible to distinguish the lots and buildings weighing on the hypogeal area of the amphitheater (Fig. 7).

Building n. 4112 facing onto Via Manzoni at the corner with Via Penninello is recognizable, as it is the 18th century palace of the Ardizzone family mentioned in the papers several times. Even today, the underlying portion of the amphitheater is the one that presents the greatest problems both in terms of static and infiltration, in accordance with what the archive papers documented several times for the past centuries. With the same ease, the area of the Villa Cerami (n. 32639) is identified, today it is the seat of the University of Catania, Department of Law, and the terrace with garden is entirely supported by the South-Western sectors and by the external ambulatory of the amphitheater. These parts of the buildings are subjecting to perennial infiltrations and consequent manifest alterations, even in this case the problems mentioned by the documents are still present today. The more-doubts remain for the identification of the other houses. Clues can be drawn from the sources documenting in 1875 the discovery of parts of the ruin in to the house belonging to a certain Mr. Puglisi and in the adjacent house of the Nicosia family, both built after 1693 in the street Via Penninello, 


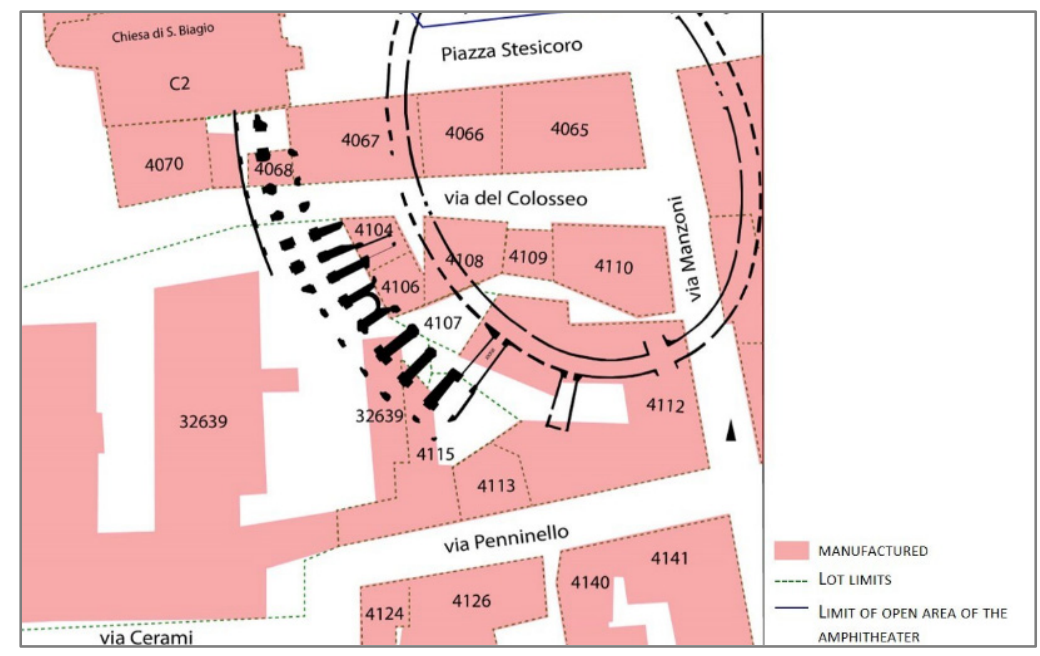

Figure 7: Framing of the amphitheater with the cadastral map of 2015 and with indication of the buildings and lots.

above the amphitheater (Prefettura, series I, list 14, envelope 258). For logic of stratification, it is possible to consider that these properties fall within the lots n. 4115 and 4113 . Not negligible, then, is the aforementioned existence of other gardens, next to the amphitheater, in addition to those of the Cerami. In particular, that of Mr. Cappellano Cosentino (Intendenza Borbonica, envelope 643, cc. 609) from which the fall of water and "garbage" is denounced in 1838 and the citation, in 1885, among the houses competing against, that of the knight Nigo (Prefettura, series I, list 14, envelope 257). The attribution to the lots for the latter cases remains more doubtful. However, it is not excluded that the knight's house may be located in the remaining blocks above the amphitheater (lots n. 4014, 4106, 4108), while the garden could coincide with lot n. 4107 , as well as the only green area in the area.

\section{CONCLUSIONS}

The archival sources relating to the historical and artistic heritage of the city of Catania and in particular to the amphitheater, clearly show how it is possible to trace a real "history of the deterioration of the amphitheater" connected to the upper urban area, coming to note how the problems that today we are faced with have actually been there for centuries [19].

Reasoning and summarizing, the areas of the amphitheater most subject to problems were the western and southern areas during the 19th century and continue to be so today. About the intervention proposals that are drawn from the documents, both active water diversion interventions by building new channels and passive interventions were suggested: closing of the parts, plugging of the entrances. At present, it is not easy to understand which ones have actually been made. Certainly, however, still at the beginning of the 19th century the problems were present so it is possible to hypothesize an actual lack of interventions up to that period. Certainly, an important fact dates back to 1870 when a document talk about the construction of a municipal road sewer in the area where the amphitheater is located, probably part of those located under Via dei Cappuccini and Piazza Stesicoro. However, this does not seem to have been designed to solve the present situations because, rather, in 1875 with private houses caused as many problems of infiltration to the ancient structure that lay 
under. Despite the interest in the intervention shown by the institutional managers, there is a lack of timeliness and indeed a predominance of the abusive private action. We can remember the interventions carried out on the vaults of the amphitheater by the Prince of Cerami, the uncontrolled construction of canals that convey waters and the use of the ancient rooms as places of unloading. These practices are also found in other archaeological sites in Catania; as demonstrated by the construction of a latrine in a house built above the second corridor of the Roman theater (Prefettura, list 33, envelope 59). What, in conclusion, the archival research shows is that the problems with which we have to face today have already characterized the life of the amphitheater for centuries. These problems must obviously be traced back to the articulated stratification system that unites a building born to be above ground to an urban and plant context that spontaneously stratifies above it and incorporates it following a culture that does not care about antiquities but is projected towards reconstruction. To approach the problems, in addition to a study that combines the archeology of architecture with the analysis of urban transformations, an area to be investigated to trace the causes of the problems certainly concerns the systems of the inhabited areas and the urban area above the amphitheater. On this theme, from the examination of the sources, a precise provision is not deduced, at most we note an illicit exploitation of the underlying amphitheater with direct drains. Private individuals used to build gathering canals which they unloaded in illegally arranged points with, as we have seen, negative consequences. The drains, such as those of the Ardizzone's house, still present today, or of the sacristies, often exploited voids and pockets of the land according to a "disposable" system widespread in the city and seen both in the amphitheater and in the theater. This condition is very likely to still be active today, just as it is likely that the systems built in a careless way have never been modified or diverted from the archaeological area. Today the conditions of the plant system of the city are very complex [20], without going into much detail on the theme, it is difficult to understand how the individual building complexes that affect the area of the amphitheater are set up. However, it is indisputable that this situation is as in general the development over time of an urban system that incorporates an older one, lead to consequences that are not easy to investigate. In addition, to the losses caused by underground discharges in the concurrence of the causes, the external rainwater drainage systems and the burials that lean against the building, even more difficult to manage than plant engineering, should not be underestimated. Any restoration or large-scale intervention in urban terms, therefore aimed at blocking the ongoing process, cannot exclude an accurate analysis of all these situations.

\section{ACKNOWLEDGEMENT}

We would like to thank the Ministero dell'Istruzione, dell'Università e della Ricerca who financed the project EWAS - An early WArning System for Cultural Heritage - PON ARS01_00926 PNR2015-2020.

\section{REFERENCES}

[1] Correnti, S., Catania attraverso $i$ secoli, nei testi e nelle immagini, Stamperia Valdonega: Verona, 1966.

[2] Cascone, S.M., Longhitano, G.A., Longhitano, L. \& Tomasello, N., Dallo studio archeologico delle malte storiche alla prospettabile progettazione delle malte da restauro attraverso una procedura di metodo. Case study: le Terme Achilliane di Catania. Conference Proceeding in Colloqui.AT.e 2020 - Nuovi orizzonti per l'architettura sostenibile (Catania, 9-11 dicembre 2020), 2020. 
[3] Tomasello, F., La viabilità suburbana in età imperiale. Tra lava e mare, Contributi all'archaiologhia di Catania, Edizioni private e varie, eds M.G. Branciforti \& V. La Rosa, Le Nove Muse Editrice: Catania, pp. 289-318, 2010.

[4] Privitera, S., Lo sviluppo urbano di Catania dalla fondazione dell'apoikia alla fine del V secolo d.C. Catania. L'identità urbana dall'antichità al settecento, ed. L. Scalisi, Sanfilippo: Catania, pp. 37-71, 2009.

[5] Boschi, E. \& Guidoboni, E., Catania. Terremoti e lave dal mondo antico alla fine del Novecento, Editrice Compositori: Roma, 2001.

[6] Dato, G., La città di Catania, Officina Edizioni: Catania, 1983.

[7] Basile, F. \& Magnano di San Lio, E., Orti e Giardini dell'aristocrazia catanese, Sicania: Messina, 1996.

[8] Cantone, U., La Chiesa di S. Agata al Carcere a Catania. Quaderni dell'Istituto di disegno 2, Tip, dell'Universita: Catania, pp. 215-240, 1964-1965.

[9] Bonaventura, V., La Sicilia al tempo del Grand Tour, GBM: Messina, 2009.

[10] Beste, H., Becker, F. \& Spigo, U., Studio e rilievo sull'anfiteatro romano di Catania. Rapporto preliminare sul rilievo archeologico - Recente campagna di indagini. Bullettino dell'Istituto Archeologico Germanico, 113, pp. 595-613, 2007.

[11] Malfitana, D. \& Mazzaglia, A., Archeologia globale a Catania. Nuove prospettive dall'integrazione di ricerca archeologica e tecnologie ICT. Nuovi dati sull'anfiteatro romano. Studi e materiali 1, Dipartimento culture e società - sezione beni culturali area archeologia Università di Palermo, Palermo, pp. 327-353, 2018.

[12] Longhitano, L., L'anfiteatro romano di catania settore XXXVI. Ricerca storica, stratigrafia degli elevati, prima diagnostica per la verifica delle condizioni di conservazione. Thesis, Politecnico di Milano, 2018-2019.

[13] Pelagatti, P., Dalla Commissione Antichità e Belle Arti di Sicilia (CABAS) alla amministrazione delle Belle Arti nella Sicilia post-unitaria. Rottura e continuità amministrativa. Mélanges de l'école française de Rome Année, pp. 599-621, 2001.

[14] Iozzia, A.M., Documenti dell'Archivio di Stato di Catania per la storia dell'archeologia catanese. 1743-1932. Catania antica nuove prospettive di ricerca, ed. F. Nicoletti, Grafica Saturnia: Siracusa, pp. 673-720, 2015.

[15] Oteri, A.M., Tutela dei monumenti antichi e trasformazioni urbane a Catania, 17791949. Aree Archeologiche e centri storici. Costruzione dei Parchi archeologici e processi di trasformazione urbana, ed. G.P. Treccani, FrancoAngeli: Milano, pp. 153186, 2011.

[16] Muscolino, F., Il principe di Biscari e il principe di Torremuzza «i due Dioscuri della passione antiquaria settecentesca». LANX, 21, pp. 1-40, 2015.

[17] Ottorino Russo, A.G., Catania e il suo Settecento, Tringale Editore: Catania, 1984.

[18] Sciuto Patti, S., I recenti restauri dei Monumenti antichi di Catania, l'Odeon, l'Anfiteatro romano, il Teatro greco, il Foro sotto l'ispettorato dell'Ing. S. Sciuto-Patti. Archivio Storico per la Sicilia orientale, X, I, Catania, pp. 312-315, 1913.

[19] Cascone, S.M. \& Longhitano, L., L'importanza della ricerca d'archivio per un'analisi dello stato di fatto degli edifici storici e delle cause dei fenomeni di degrado: il caso dell'anfiteatro romano di Catania. Simposio Internazionale-Assemblea dei sociREUSO (30 ottobre 2020), 2020.

[20] Murabito, L., Lo scandalo della Rete Fognaria di Catania: emergenza per gli scarichi a mare. SUD PRESS giornalismo d'inchiesta, online. www.sudpress.it. Accessed on: 11 Feb. 2021. 